\title{
Conjugated linoleic acid in diets for large-size rainbow trout (Oncorhynchus mykiss): effects on growth, chemical composition and sensory attributes
}

\author{
L. M. P. Valente ${ }^{1,2}$, N. M. Bandarra ${ }^{3}$, A. C. Figueiredo-Silva ${ }^{1}$, P. Rema ${ }^{1,4}$, P. Vaz-Pires ${ }^{1,2}$, S. Martins ${ }^{3}$, \\ J. A. M. Prates ${ }^{5}$ and M. L. Nunes ${ }^{3}$ \\ ${ }^{1}$ Centro Interdisciplinar de Investigação Marinha e Ambiental, Rua dos Bragas, 177, 4050-123 Porto, Portugal \\ ${ }^{2}$ Instituto de Ciências Biomédicas de Abel Salazar, Universidade do Porto, Largo Prof. Abel Salazar, 2, 4099-003 Porto, Portugal \\ ${ }^{3}$ Instituto de Investigação Agrária e das Pescas, Departamento de Inovação Tecnológica e Valorização dos Produtos da Pesca, \\ Av. Brasília, 1449-006 Lisboa, Portugal \\ ${ }^{4}$ Departamento de Zootecnia, Universidade de Trás-os-Montes e Alto-Douro, Apartado 1013, 5000-911 Vila Real, Portugal \\ ${ }^{5}$ Faculdade de Medicina Veterinária, Rua Prof. Cid dos Santos, Pólo Universitário do Alto da Ajuda, 1300-477 Lisboa, Portugal
}

(Received 14 December 2005 - Revised 20 July 2006 - Accepted 26 July 2006)

\begin{abstract}
The effects of graded levels $(0 \%, 0.5 \%, 0.75$ and $1 \%)$ of dietary conjugated linoleic acid (CLA) were assessed on $97 \mathrm{~g}$ rainbow trout. Fish were fed to satiation twice a day for 12 weeks. At the end of the experiment, all groups of fish weighed more than $250 \mathrm{~g}$ and no significant differences were detected in growth performance, feed conversion, nutrient or energy utilisation or body composition between treatments. A decrease in liver lipid content resulted from including CLA and was accompanied by a reduction in malic enzyme activity. The muscle saturated acid and PUFA content did not vary between dietary treatments, despite the increasing concentration of stearic acid and CLA. In the liver, however, both fractions increased significantly with dietary CLA. Moreover, the MUFA decreased significantly in both muscle and liver. CLA was incorporated into tissue lipids, with levels in flesh $(2 \cdot 1-4.2 \%)$ being 2 -fold higher than in liver $(0.8-1.9 \%)$. In muscle, the percentage of cis-9,trans-11 isomer ranged from $39.5 \%$ to $41.8 \%$ and that of trans-10,cis-12 isomer from $31.4 \%$ to $33.4 \%$ of total CLA. The incorporation of CLA isomers in the liver varied with dietary treatment, and the cis-9,trans-11 isomer seemed to be more efficiently incorporated than trans-10, cis-12. Sensory data indicated slight-to-moderate differences between the trout fed with and without CLA. The present results suggest that $250 \mathrm{~g}$ rainbow trout can incorporate CLA in both muscle and liver, contributing to the production of a functional food.
\end{abstract}

Rainbow trout: Conjugated linoleic acid: Growth: Lipid: Fatty acid composition: Lipogenesis

The current trend in fish production is to increase the lipid content in diets to spare proteins, improve feed conversion and decrease the amount of waste produced by fish. These diets, however, alter body composition and slaughter quality, particularly through an increase in lipid deposition (Cowey, 1993; Hillestad \& Johnsen, 1994; Vergara et al. 1999). The farming industry is concerned with finding methods that control body lipid deposition and/or increase the market value of cultured fish when such diets are used.

Conjugated linoleic acids (CLA) is a collective term for isomers of $\mathrm{C}_{18: 2}$ fatty acids that differ in the geometry and position of two conjugated double bonds. Research with CLA indicates that these fatty acids are responsible for many biological properties that relate to health. CLAs have been shown to inhibit atherosclerosis (Lee et al. 1994), chemically induced carcinogenesis (Ha et al. 1990; Ip et al. 1999) and obesity (Park et al. 1997; West et al. 1998) and to enhance feed efficiency (Li \& Watkins, 1998) in several rodent models. In addition, dietary CLA has been reported to decrease body fat in mice (Park et al. 1997), rats (Sisk et al. 2001), pigs (Ostrowska et al. 1999) and chickens (Szymczyk et al. 2001), although in man the results are limited and contradictory (Risérus et al. 2002, 2003; Gaullier et al. 2005).

In fish, studies with CLA are very scarce, but in certain species, CLAs have been shown to alter growth responses, feed efficiency and lipid deposition (Choi et al. 1999; Twibell et al. 2000, 2001; Twibell \& Wilson, 2003). Dietary CLA did not, however, affect the growth performance or proximate composition of rainbow trout (Figueiredo-Silva et al. 2005) or Atlantic salmon juveniles (Berge et al. 2004; Kennedy et al. 2005), although the fatty acid profile of those fish was strongly modified (Berge et al. 2004; Bandarra et al. 2006). Fish are not a naturally rich source of CLA but are capable of incorporating high levels of CLA into tissue lipids after dietary supplementation (Twibell et al. 2000, 2001; Kennedy et al. 2005; Bandarra et al. 2006), this being a suitable route to produce 'functional foods'.

High-lipid diets result in a marked increase in the flesh lipid content of fish, which is a component of organoleptic quality (Corraze, 2001). Fattening makes the raw flesh more tender

Abbreviation: CLA, conjugated linoleic acid.

* Corresponding author: L. M. P. Valente, tel +351 2234018 25, fax +351 223390608 , email lvalente@icbas.up.pt 
and slightly modifies the consumer's overall taste perception. The nature of the dietary lipids also affects the taste of the products (Boggio et al. 1985; Turchini et al. 2003; Izquierdo et al. 2005), but very little is known about the general effects of these alterations, particularly dietary CLA supplementation, on the sensory characteristics of rainbow trout.

The overall objective of the present study was to evaluate the effect of graded levels of CLA in high-fat diets fed to large-size rainbow trout. The growth performance, body composition, tissue fatty acid deposition, lipogenic enzyme activities (glucose-6-phosphate dehydrogenase, malic enzyme, fatty acid synthetase) and sensory characteristics of the flesh were then assessed using those fish.

\section{Material and methods}

\section{Experimental diets}

A commercial extruded diet for rainbow trout was supplied by Sorgal S.A. (Ovar, Portugal). The CLA mixture (containing $75 \%$ CLA) was offered by Bioriginal Food and Science Corp. (Saskatoon, SK, Canada). Before oil-coating, the pellets (3 mm diameter) were analysed for proximate composition and then coated with $21.9 \%$ oil containing the different CLA levels $(0 \%, 0.5 \%, 0.75 \%, 1 \%)$. The CLA supplement was added to the diets at the expense of fish oil to maintain a constant energy level $(25-26 \mathrm{~kJ} / \mathrm{g}$ DM) between dietary treatments. The ingredients and proximate composition of the experimental diets are presented in Table 1 and the fatty acid profiles in Table 2.

Table 1. Ingredients and proximate composition of diets with different levels $(0 \%, 0.5 \%, 0.75 \%, 1 \%)$ of conjugated linoleic acid (CLA)

\begin{tabular}{lrrrr}
\hline & \multicolumn{4}{c}{ CLA dietary level (\%) } \\
\cline { 2 - 5 } & \multicolumn{1}{c}{0} & 0.5 & 0.75 & \multicolumn{1}{c}{1} \\
\hline Ingredients (\%) & & & & \\
$\quad$ Fish meal & 96.99 & 46.99 & 46.99 & 46.99 \\
$\quad$ Corn gluten meal & 9.72 & 9.72 & 9.72 & 9.72 \\
Extruded peas meal & 6.94 & 6.94 & 6.94 & 6.94 \\
Brewer's yeast & 0.97 & 0.97 & 0.97 & 0.97 \\
Soyabean molasses & 9.61 & 9.61 & 9.61 & 9.61 \\
Fish oil & 21.87 & 21.21 & 20.87 & 20.54 \\
CLA† & 0.00 & 0.67 & 1.00 & 1.33 \\
Vitamin $\ddagger$ and mineral mix§ & 3.89 & 3.89 & 3.89 & 3.89 \\
Proximate composition & & & & \\
DM (\%) & 92.63 & 92.71 & 92.75 & 92.86 \\
Crude protein (\% DM) & 45.53 & 45.97 & 45.91 & 45.99 \\
Crude fat (\% DM) & 29.79 & 29.82 & 29.83 & 29.50 \\
Ash (\% DM) & 10.59 & 10.38 & 10.27 & 10.31 \\
Gross energy (kJ/g DM) & 25.86 & 26.37 & 26.11 & 25.85 \\
& & & & \\
\end{tabular}

*Aquatex (20.5 crude protein); Sotexpro, Bermericourt, France.

†CLA mixture: total CLA, $75 \%$; 18:2 (cis-9,trans-11), 33.6\%; 18:2 (trans10,cis-12), $32.5 \%$

¥Vitamins (mg/kg diet or IU/kg diet): vitamin A, $8000 \mathrm{IU}$; vitamin $\mathrm{D}_{3}, 2000 \mathrm{IU}$; vitamin $\mathrm{E}, 100 \mathrm{mg}$; vitamin $\mathrm{K}, 10 \mathrm{mg}$; vitamin $\mathrm{B}_{12}, 0.02 \mathrm{mg}$; vitamin $\mathrm{B}_{1}, 15 \mathrm{mg}$; vitamin $B_{2}, 25 \mathrm{mg}$; vitamin $B_{6}, 15 \mathrm{mg}$; folic acid, $10 \mathrm{mg}$; biotin, $1 \mathrm{mg}$; vitamin $C$, $100 \mathrm{mg}$; betaine, $500 \mathrm{mg}$; inositol, $300 \mathrm{mg}$; nicotinic acid, $100 \mathrm{mg}$; pantothenic acid, $50 \mathrm{mg}$; choline chloride, $1000 \mathrm{mg}$.

$\S$ Minerals ( $\mathrm{g} / \mathrm{kg}$ diet or $\mathrm{mg} / \mathrm{kg}$ diet): $\mathrm{MnSO}_{4}, 20 \mathrm{mg} ; \mathrm{Kl}, 0.6 \mathrm{mg} ; \mathrm{CuSO}_{4}, 5 \mathrm{mg}$; $\mathrm{CoSO}_{4}, 0.4 \mathrm{mg} ; \mathrm{MgSO}_{4}, 500 \mathrm{mg} ; \mathrm{Zn}$ (Bioplex; Allech), $30 \mathrm{mg}$; Se (Sel-Plex 2000; Allech), $0.3 \mathrm{mg} ; \mathrm{FeSO}_{4}, 40 \mathrm{mg} ; \mathrm{CaCO}_{3}, 2.15 \mathrm{~g}$; dibasic calcium phosphate, $5 \mathrm{~g} ; \mathrm{KCl}, 1 \mathrm{~g} ; \mathrm{NaCl}, 0.4 \mathrm{~g}$.

\section{Growth trial}

The trial was conducted with rainbow trout (Oncorhynchus mykiss) juveniles produced at the University of Trás-osMontes and Alto Douro (UTAD, Vila Real, Portugal) rearing facilities. Fish were acclimated to the experimental conditions and fed the control diet $(<0.003 \%$ CLA) for a period of 2 weeks before the beginning of the experiment. Homogenous groups of twenty-five fish with an average initial body weight of 97.8 (SD 0.02) $\mathrm{g}$ were then randomly distributed between twelve square fibre-glass tanks (250 litres) in an open flow-through system. Triplicate groups of fish for each treatment were hand-fed to apparent satiety twice a day $(09.30$ and $18.00 \mathrm{~h})$ for 12 weeks. The $\mathrm{pH}$, ammonia, nitrite, nitrate and phosphate levels were monitored during the entire trial and maintained at levels compatible with the species. The daily water temperature was $16 \pm 1^{\circ} \mathrm{C}$ and fish were exposed to natural photoperiod. At the end of the growth trial, data on weight gain and feed intake were collected from all the fish. Prior to sampling, fish were fasted for $24 \mathrm{~h}$ and then anaesthetised by immersion in an ethylene glycol monophenyl ether (1:2500) bath. A pooled sample of six fish from the initial stock at the beginning of the experiment and three fish per tank at the end of the experiment were taken and stored at $-20^{\circ} \mathrm{C}$ for subsequent whole-body composition analyses.

At the end of the experiment, liver and viscera from nine fish per dietary treatment were removed and weighed for estimation of the hepatosomatic and viscerosomatic indices. The livers and muscle samples from nine fish per treatment were removed and frozen in liquid $\mathrm{N}$ and stored at $-80^{\circ} \mathrm{C}$ prior to fatty acid determination and analysis of lipogenic enzymes activity. Experiments were conducted according to the European Council Directive 86/609/EEC regarding the protection of animals used for experimental and other scientific purposes.

\section{Analytical methods}

Whole fish were ground, and their moisture content was determined $\left(105^{\circ} \mathrm{C}\right.$ for $\left.24 \mathrm{~h}\right)$. Fish were subsequently freeze-dried before further analysis. Feed, whole-body samples and faeces were then analysed for DM $\left(105^{\circ} \mathrm{C}\right.$ for $\left.24 \mathrm{~h}\right)$, ash by combustion in a muffle furnace $\left(550^{\circ} \mathrm{C}\right.$ for $12 \mathrm{~h}$ ), crude protein (Micro-Kjeldahl; $\mathrm{N} \times 6.25$ ) after acid digestion, lipid content by petroleum ether extraction (at Soxhlet $40-60^{\circ} \mathrm{C}$ ) and gross energy in an adiabatic bomb calorimeter (IKA, Staufen, Germany).

Determinations of the total lipid of the fish tissues were carried out following the Bligh \& Dyer (1959) method with small modifications. Muscle samples were analysed individually, whereas in liver, owing to the scarcity of individual samples, the three livers per tank were sliced and divided into two samples that were analysed independently.

Fatty acid methyl esters (FAME) of diets were prepared after lipid extraction carried out according to the methodology of Bligh \& Dyer (1959), followed by acid modified transesterification for $2 \mathrm{~h}$ at $80^{\circ} \mathrm{C}$. To analyse the fatty acid methyl esters and CLA of trout muscle and liver, extracted total lipids were used for methyl ester preparation by base-catalysed transesterification, with $0.5 \mathrm{M}$-sodium methoxide solution in anhydrous methanol $\left(2 \mathrm{~h}\right.$ at $\left.30^{\circ} \mathrm{C}\right)$, as proposed by Park et al. (2001) and Kramer et al. (2002), in order to avoid the isomerisation 
Table 2. Fatty acid profile (\% total fatty acids) and total conjugated linoleic acid (CLA) content and CLA isomers (\% total lipids) of diets with different levels of CLA ( $0 \%, 0.5 \%, 0.75 \%$ and $1 \%)$

(Mean values and standard deviations for three determinations)

\begin{tabular}{|c|c|c|c|c|c|c|c|c|c|}
\hline & \multicolumn{8}{|c|}{ CLA dietary level (\%) } & \multirow[b]{3}{*}{ ANOVA $P$ value } \\
\hline & \multicolumn{2}{|c|}{0} & \multicolumn{2}{|c|}{0.5} & \multicolumn{2}{|c|}{0.75} & \multicolumn{2}{|c|}{1} & \\
\hline & Mean & SD & Mean & SD & Mean & SD & Mean & SD & \\
\hline \multicolumn{10}{|l|}{ Fatty acids (\%) } \\
\hline $14: 0$ & $5 \cdot 95^{\mathrm{a}}$ & 0.06 & $5 \cdot 37^{\mathrm{ab}}$ & 0.35 & $5.03^{b}$ & 0.06 & $5 \cdot 23^{a b}$ & 0.03 & 0.044 \\
\hline $16: 0$ & $17 \cdot 33$ & 0.12 & $16 \cdot 35$ & 0.99 & $15 \cdot 49$ & 0.21 & $16 \cdot 45$ & 0.03 & 0.055 \\
\hline $18: 0$ & 3.42 & 0.02 & 3.56 & 0.22 & 3.52 & 0.05 & 3.55 & 0.01 & 0.250 \\
\hline$\Sigma$ Saturated ${ }^{*}$ & 28.59 & 0.21 & $27 \cdot 38$ & 1.65 & $25 \cdot 87$ & 0.28 & $27 \cdot 00$ & 0.03 & 0.055 \\
\hline $16: 1$ & $7 \cdot 78^{\mathrm{a}}$ & 0.04 & $5.43^{\mathrm{ab}}$ & 0.41 & $5 \cdot 04^{\mathrm{b}}$ & 0.04 & $6 \cdot 71^{\mathrm{ab}}$ & 0.01 & 0.020 \\
\hline $18: 1 n-9$ & $14 \cdot 59^{\mathrm{ab}}$ & 0.05 & $15 \cdot 64^{\mathrm{a}}$ & 0.87 & $14 \cdot 90^{\mathrm{ab}}$ & 0.12 & $14 \cdot 27^{\mathrm{b}}$ & 0.08 & 0.025 \\
\hline $20: 1$ & $4.77^{\mathrm{ab}}$ & 0.02 & $5 \cdot 15^{\mathrm{ab}}$ & 0.28 & $5 \cdot 31^{\mathrm{a}}$ & 0.09 & $4 \cdot 68^{b}$ & 0.03 & 0.021 \\
\hline$\Sigma$ Monounsaturated $\dagger$ & 32.54 & $0 \cdot 10$ & $32 \cdot 20$ & 1.94 & $31 \cdot 32$ & 0.54 & $30 \cdot 64$ & 0.08 & 0.190 \\
\hline $16: 2 n-4$ & $0 \cdot 27$ & 0.01 & 0.18 & $0 \cdot 16$ & 0.24 & 0.003 & 0.23 & 0.01 & 0.150 \\
\hline $16: 3 n-3$ & $0.32^{\mathrm{a}}$ & 0.002 & $0.31^{\mathrm{ab}}$ & 0.02 & $0.29^{a b}$ & 0.002 & $0.28^{\mathrm{b}}$ & 0.001 & 0.024 \\
\hline $18: 2 n-6$ & $3 \cdot 13$ & 0.01 & 3.79 & 0.19 & $3 \cdot 61$ & 0.05 & 3.62 & 0.02 & 0.077 \\
\hline $18: 2$ CLA & $0.003^{\mathrm{a}}$ & 0.001 & $2 \cdot 50^{\mathrm{b}}$ & 0.07 & $3.86^{\mathrm{C}}$ & $0 \cdot 10$ & $4.59^{d}$ & 0.08 & 0.000 \\
\hline $18: 3 n-3$ & 1.05 & 0.003 & $1 \cdot 21$ & $0 \cdot 10$ & $1 \cdot 17$ & 0.09 & 1.02 & 0.01 & 0.025 \\
\hline $18: 4 n-3$ & 2.59 & 0.02 & 2.90 & 0.12 & $2 \cdot 79$ & 0.09 & $2 \cdot 81$ & 0.02 & 0.077 \\
\hline $20: 4 n-6$ & $1.03^{\mathrm{a}}$ & 0.01 & $0.90^{\mathrm{bc}}$ & 0.05 & $0.85^{\mathrm{b}}$ & 0.02 & $0.94^{\mathrm{C}}$ & 0.004 & 0.024 \\
\hline $20: 4 n-3$ & $0.92^{\mathrm{a}}$ & 0.01 & $0 \cdot 80^{\mathrm{bc}}$ & 0.04 & $0.79^{\mathrm{b}}$ & 0.02 & $0.85^{\mathrm{c}}$ & 0.01 & 0.0002 \\
\hline $20: 5 n-3$ & $12 \cdot 25^{\mathrm{a}}$ & 0.10 & $7.99^{b}$ & 0.44 & $7 \cdot 81^{\mathrm{b}}$ & 0.19 & $11.33^{c}$ & 0.01 & 0.024 \\
\hline $22: 5 n-6$ & $0.31^{\mathrm{ab}}$ & 0.01 & $0.33^{a}$ & 0.01 & $0.33^{a}$ & 0.01 & $0.29^{b}$ & 0.01 & 0.003 \\
\hline $22: 5 n-3$ & $1.55^{\mathrm{a}}$ & 0.03 & $1.31^{\mathrm{b}}$ & 0.08 & $1 \cdot 31^{\mathrm{b}}$ & 0.05 & $1.50^{\mathrm{a}}$ & 0.01 & 0.0004 \\
\hline $22: 6 n-3$ & $10 \cdot 13^{\mathrm{ab}}$ & $0 \cdot 10$ & $10 \cdot 63^{\mathrm{ab}}$ & 0.58 & $10 \cdot 82^{\mathrm{a}}$ & 0.40 & $9 \cdot 84^{\mathrm{b}}$ & 0.04 & 0.045 \\
\hline$\sum$ Polyunsaturated $\ddagger$ & $35 \cdot 76$ & 0.23 & 34.27 & 1.89 & 34.71 & 0.87 & $39 \cdot 30$ & 0.19 & 0.025 \\
\hline Total CLA (\%)§ & $0.07^{\mathrm{a}}$ & 0.02 & $2 \cdot 10^{\mathrm{ab}}$ & 0.09 & $2 \cdot 52^{\mathrm{ab}}$ & 0.26 & $3.50^{\mathrm{b}}$ & 0.75 & 0.016 \\
\hline $18: 2$ cis-9,trans- $11(\%) \|$ & $0.05^{a}$ & 0.00 & $0.35^{\mathrm{b}}$ & 0.02 & $0.58^{\mathrm{C}}$ & $0 \cdot 10$ & $0.85^{d}$ & 0.13 & 0.000 \\
\hline 18.2 trans- 10, cis- $12(\%) \|$ & $0.02^{a}$ & 0.00 & $0 \cdot 17^{\mathrm{b}}$ & 0.03 & $0.30^{C}$ & $0 \cdot 10$ & $0.50^{d}$ & 0.06 & 0.000 \\
\hline
\end{tabular}

a,b,c,d Mean values with unlike superscript letters were significantly different $(P<0.05)$

* Saturated: $12: 0,14: 0,14: 0$ isobr, 15:0,16:0,16:0 isobr, 17:0,18:0,19:0,20:0,22:0 and $24: 0$

† Monounsaturated: $16: 1 n-7,17: 1 n-8,18: 1 n-9,18: 1 n-7,20: 1 n-9,20: 1 n-7,22: 1 n-11$ and $22: 1 n-9$.

‡Polyunsaturated: 16:2n-4, 16:3n-3, 16:4n-3, 18:2n-6, 18:2CLA, 18:3n-6, 18:3n-3, 18:4n-3, 20:2n-6, 20:3n-3, 20:4n-6, 20:4n-3, 20:5n-3, 22:2n-6, 22:4n$6,22: 5 n-6,22: 5 n-3$ and $22: 6 n-3$

$\S$ Sum of all CLA isomers detected by HPLC.

|| Isomers detected by HPLC.

of CLA. Fatty acid methyl esters prepared in triplicate were analysed in a Varian CP 3800 (Walnut Creek, CA, USA) GC, equipped with an autosampler and fitted with a flame ionisation detector at $250^{\circ} \mathrm{C}$. The separation was achieved using a capillary column HP-Innowax (30 m length, $0.25 \mathrm{~mm}$ internal diameter, 0.25 ( $\mathrm{m}$ film thickness) from Agilent (Albertville, $\mathrm{MN}$, USA). After being kept constant at $180^{\circ} \mathrm{C}$ for $5 \mathrm{~min}$, the temperature was raised by $4^{\circ} \mathrm{C} / \mathrm{min}$ to $220^{\circ} \mathrm{C}$ and maintained at $220^{\circ} \mathrm{C}$ for $25 \mathrm{~min}$ with the injector at $250^{\circ} \mathrm{C}$. The split ratio was 100:1, and quantification was carried out using an area of the internal standard of 21:0. All analytical determinations were done in triplicate.

In order to avoid some possible co-elution of individual CLA isomers using a short GC column ( $30 \mathrm{~m})$, the methyl esters of the CLA isomers were individually separated by triple Ag ion columns in series (ChromSpher 5 Lipids; $250 \mathrm{~mm}^{\prime} 4.6 \mathrm{~mm}$ internal diameter, $5 \mu \mathrm{m}$ particle size; Chrompack, Bridgewater, NJ, USA), using an HPLC system (Agilent 1100 Series; Agilent Technologies Inc., Palo Alto, CA, USA) equipped with an autosampler and diode array detector adjusted to $233 \mathrm{~nm}$. The mobile phase was $0 \cdot 1 \%$ acetonitrile in $n$-hexane maintained at a flow rate of $1 \mathrm{ml} / \mathrm{min}$, using injection volumes of $20 \mu \mathrm{l}$. The identification of the individual CLA isomers was achieved by comparing their retention times with commercial and prepared standards, as well as with values published in the literature In addition, the identification of each isomer was controlled by the typical UV spectra of CLA isomers from the diode array detector in the range 190 to $360 \mathrm{~nm}$, using the spectral analysis of Agilent Chemstation for LC 3D Systems rev. A.09.01 (Agilent Technologies). The determination of total and individual CLA isomer content was based on the external standard technique (using 18:2 cis-9,trans-11, 18:2 trans-10,cis-12, 18:2 cis-9,cis-11 and 18:2 trans-9,trans-11 as representatives of each of the geometric groups of CLA isomers) and on the method of area normalisation (Association of Official Analytical Chemists, 2000). The CLA isomers were expressed in gravimetric contents as percentages of total lipids (g/100 g lipids).

\section{Enzyme assays}

Liver samples were homogenised in three volumes of ice-cold buffer $0.02 \mathrm{M}$-Tris- $\mathrm{HCl}, 0 \cdot 25 \mathrm{M}$-sucrose, $2 \mathrm{mM}$-EDTA, $0 \cdot 1 \mathrm{M}$ $\mathrm{NaF}, 0.5 \mathrm{~m}$ M-phenyl methyl sulphonyl fluoride and $0.01 \mathrm{M}-$ $\beta$-mercaptoethanol at $\mathrm{pH} 7.4$ and centrifuged $(30000 \mathrm{~g}$ at $4^{\circ} \mathrm{C}$ ) for $20 \mathrm{~min}$. The soluble protein content of the liver was determined in the supernatant by the method of Bradford (1976) using bovine serum albumin as a standard. Selected lipogenic enzyme activities were assayed on the supernatant 
using spectrophotometric procedures: glucose-6-phosphate dehydrogenase (EC 1.1.1.49) according to Bautista et al. (1988), malic enzyme (ME, EC 1.1.1.40) according to Ochoa (1955) and fatty acid synthetase (EC 2.3.1.38) according to the methodology of Chang et al. (1967) as modified by Chakrabarty \& Leveille (1969). Enzyme activity units (IU), defined as millimoles of substrate converted to product per minute at the assay temperature, were expressed per milligrams of hepatic soluble protein-specific activity. In order to take into account possible variations in the hepatosomatic index, the activities were also calculated per $100 \mathrm{~g}$ of fish.

\section{Sensory analysis}

At the end of the experiment, four fish per tank were killed by a sharp blow on the head and immediately put on ice. They were then stored for $24 \mathrm{~h}$ at $4^{\circ} \mathrm{C}$ before sensory analysis. The same protocol of slaughter and filleting was strictly applied to all the fish. The fillets were skinned, washed with tap water and hand-cut into $20 \mathrm{~g}$ portions. These were then put into small plastic cups previously coded with three-digit numbers and microwaved until homogeneous cooking $(20 \mathrm{~s}$ at a maximum power of $850 \mathrm{~W}$ ). Samples were randomised and served hot in a consumer-type test to thirty-one panelists who regularly ate fish, who were asked to compare unknown samples with an identified control ( $0 \%$ CLA), in a room designed for sensory analysis. A hidden control was included among the samples to be classified. An explanation sheet with detailed instructions and questions to be answered was given to each panelist. The samples were evaluated using a scale from 0 (similar to control) to 6 (extremely different from control). If sensory differences were detected between the samples, panelists were asked to describe them to obtain a general idea of attributes of the different fish.

\section{Statistical analysis}

Statistical analyses followed methods outlined by Zar (1996). All data were tested for normality and homogeneity of variances by Kolmogorov-Smirnov and Bartlett tests, and were then submitted to a one-way ANOVA with the Statistica 6.0 package for Windows (StatSoft Inc., Tulsa, OK, USA). When data did not meet the assumptions of ANOVA, the non-parametric ANOVA equivalent (Kruskal-Wallis test) was performed. When these tests showed significance $(P<0.05)$, individual means were compared using the Tukey or Dunn test. The results of sensory analysis were subjected to two-way ANOVA to test the effects of experimental diets and assessors, this being followed by a Dunnett test. Significant differences were considered when $P<0 \cdot 05$.

\section{Results}

Rainbow trout fed the experimental diets during 12 weeks did not display significant differences in growth performance $(2-2 \cdot 3 \%)$, feed conversion ratio $(1 \cdot 1-1 \cdot 2)$, protein efficiency ratio $(1.8-2 \cdot 0)$ or feed intake $(12.6-12.9 \mathrm{~g} / \mathrm{kg}$ per day) between treatments (Table 3 ). Furthermore, neither the hepatosomatic $(0.8-0.9)$ nor the viscerosomatic $(9.8-11)$ index was affected by the dietary inclusion of CLA $(P>0 \cdot 1)$.

Data on the whole-body composition and retention of rainbow trout fed the different diets are presented in Table 4. By the end of the feeding trial, whole-body protein and lipid content were similar between treatments, ranging from $15.8 \%$ to $16.5 \%$ and $14.9 \%$ to $16.5 \%$, respectively. Moreover, no significant differences were observed for protein, lipid and energy retention values between dietary treatments $(P>0 \cdot 1)$.

The fatty acid profile of the rainbow trout muscle is presented in Table 5. Total saturated fatty acid, MUFA and PUFA were not

Table 3. Effect of different dietary levels ( $0 \%, 0.5 \%, 0.75 \%, 1 \%)$ of conjugated linoleic acid (CLA) on growth, efficiency and feed intake in rainbow trout over 12 weeks

(Mean values and standard deviations ${ }^{*}$ )

\begin{tabular}{|c|c|c|c|c|c|c|c|c|c|}
\hline & \multicolumn{8}{|c|}{ CLA dietary level (\%) } & \multirow[b]{3}{*}{ ANOVA $P$ value } \\
\hline & \multicolumn{2}{|c|}{0} & \multicolumn{2}{|c|}{0.5} & \multicolumn{2}{|c|}{0.75} & \multicolumn{2}{|c|}{1} & \\
\hline & Mean & SD & Mean & SD & Mean & SD & Mean & SD & \\
\hline \multicolumn{10}{|l|}{ Growth } \\
\hline Initial mean body weight & $97 \cdot 85$ & 0.06 & $97 \cdot 78$ & $0 \cdot 15$ & $97 \cdot 72$ & 0.07 & $97 \cdot 61$ & 0.02 & 0.541 \\
\hline Final mean body weight & $280 \cdot 85$ & $18 \cdot 86$ & $275 \cdot 57$ & $15 \cdot 66$ & $247 \cdot 29$ & $12 \cdot 44$ & $262 \cdot 91$ & $6 \cdot 66$ & 0.076 \\
\hline Hepatosomatic index† & 0.88 & 0.11 & 0.81 & $1 \cdot 11$ & 0.89 & 0.12 & 0.88 & 0.08 & 0.361 \\
\hline Viscerosomatic index $\ddagger$ & 9.79 & 1.61 & $10 \cdot 53$ & 1.94 & $10 \cdot 98$ & 1.77 & $10 \cdot 44$ & 1.54 & 0.539 \\
\hline Feed conversion ratio§ & $1 \cdot 13$ & 0.07 & $1 \cdot 16$ & 0.06 & $1 \cdot 24$ & 0.06 & $1 \cdot 16$ & 0.04 & 0.163 \\
\hline Daily growth index\| & $2 \cdot 31$ & $0 \cdot 18$ & $2 \cdot 26$ & $0 \cdot 15$ & 1.99 & 0.12 & $2 \cdot 14$ & 0.06 & 0.076 \\
\hline Protein efficiency ratio & 1.95 & $0 \cdot 12$ & 1.88 & $0 \cdot 10$ & 1.75 & 0.08 & 1.88 & 0.07 & 0.155 \\
\hline \multicolumn{10}{|c|}{ Intake $(\mathrm{g} / \mathrm{kg} \text { or } \mathrm{kJ} / \mathrm{kg} \text { average body weight } / \mathrm{d})^{\star \star}$} \\
\hline DM & 12.93 & 0.41 & $12 \cdot 83$ & $0 \cdot 11$ & $12 \cdot 80$ & 0.04 & $12 \cdot 60$ & 0.34 & 0.547 \\
\hline Protein & $5 \cdot 89$ & 0.19 & $5 \cdot 90$ & 0.05 & $5 \cdot 88$ & 0.02 & $5 \cdot 80$ & $0 \cdot 16$ & 0.746 \\
\hline Lipid & $3 \cdot 85$ & 0.12 & $3 \cdot 82$ & 0.03 & $3 \cdot 82$ & 0.01 & 3.72 & $0 \cdot 10$ & 0.266 \\
\hline Energy & 334.40 & 10.55 & $338 \cdot 32$ & $2 \cdot 82$ & 334.26 & 1.02 & 325.55 & $8 \cdot 85$ & 0.232 \\
\hline
\end{tabular}

Absence of superscripts letters indicates no significant differences between treatments $(P>0.05)$

${ }^{*} n 3$ except for hepatosomatic index and viscerosomatic index, for which $n 9$.

† Hepatosomatic index $=100 \times$ (liver weight/body weight), \%.

$\ddagger$ Viscerosomatic index $=100 \times$ (viscera weight/body weight), \%.

$\S$ Feed conversion ratio $=$ dry feed intake/weight gain

$\|$ Daily growth index $=100 \times\left((\text { final body weight })^{1 / 3}-(\text { initial body weight })^{1 / 3}\right) /$ days

ๆ Protein efficiency ratio $=$ weight gain/crude protein intake.

${ }^{\star *}$ Average body weight $=$ (initial mean body weight + final mean body weight $) / 2$. 
Table 4. Whole-body composition and retention of rainbow trout fed different levels of conjugated linoleic acid (CLA; $0 \%, 0.5 \%$, $0.75 \%, 1 \%)$ for 12 weeks

(Mean values and standard deviations for three determinations)

\begin{tabular}{|c|c|c|c|c|c|c|c|c|c|c|}
\hline & \multicolumn{9}{|c|}{ CLA dietary level (\%) } & \multirow[b]{3}{*}{ ANOVA $P$ value } \\
\hline & \multirow{2}{*}{$\frac{\text { Initial }}{\text { Mean }}$} & \multicolumn{2}{|c|}{0} & \multicolumn{2}{|c|}{0.5} & \multicolumn{2}{|c|}{0.75} & \multicolumn{2}{|c|}{1} & \\
\hline & & Mean & SD & Mean & SD & Mean & SD & Mean & SD & \\
\hline \multicolumn{11}{|c|}{ Whole-body composition } \\
\hline Moisture (\%) & 73.55 & 63.37 & 0.97 & 64.65 & 0.76 & 64.45 & 0.52 & 64.95 & 0.67 & 0.130 \\
\hline Protein (\%) & $16 \cdot 21$ & $16 \cdot 34$ & 0.18 & $15 \cdot 76$ & 0.56 & $16 \cdot 51$ & 0.73 & $15 \cdot 94$ & 0.20 & 0.273 \\
\hline Lipid (\%) & $5 \cdot 61$ & $16 \cdot 49$ & 1.65 & $16 \cdot 04$ & 0.40 & $14 \cdot 87$ & 0.19 & 14.78 & 1.07 & 0.173 \\
\hline Energy (kJ/g) & $6 \cdot 32$ & $10 \cdot 12$ & 0.62 & $9 \cdot 82$ & 0.20 & $9 \cdot 67$ & 0.19 & 9.54 & 0.31 & 0.321 \\
\hline Ash (\%) & 3.67 & 3.34 & 0.30 & 2.90 & 0.32 & 3.60 & 0.22 & 3.02 & 0.24 & 0.051 \\
\hline \multicolumn{11}{|c|}{ Retention (\% intake) } \\
\hline Protein & & 32.02 & 1.46 & 29.09 & 1.87 & $29 \cdot 33$ & 3.42 & $29 \cdot 73$ & 1.54 & 0.402 \\
\hline Lipid & & 66.48 & $6 \cdot 38$ & $63 \cdot 79$ & $2 \cdot 28$ & 56.54 & $2 \cdot 13$ & $59 \cdot 41$ & $6 \cdot 49$ & 0.129 \\
\hline Energy & & 41.74 & $2 \cdot 80$ & $38 \cdot 70$ & 1.58 & $36 \cdot 63$ & 2.07 & 38.41 & 2.75 & 0.139 \\
\hline
\end{tabular}

Absence of superscript letters indicates no significant differences between treatments $(P>0.05)$.

significantly affected by the incorporation of CLA. Moreover, muscle total lipids were similar between treatments. Within the saturated fraction, stearic acid $(18: 0)$ varied significantly with dietary CLA inclusion, although the expected decrease in $18: 1$ fatty acid was not seen. Among the PUFA, dietary CLA supplementation mainly resulted in a significant increase in

Table 5. Fatty acid profile (\% total fatty acids), total conjugated linoleic acid (CLA; \% total lipids) content, CLA isomers (\% total lipids) and total lipids (\% wet weight) in muscle of rainbow trout fed different dietary levels of CLA $(0 \%, 0.5 \%, 0.75 \%, 1 \%)$ for 12 weeks (Mean values and standard deviations for nine determinations)

\begin{tabular}{|c|c|c|c|c|c|c|c|c|c|}
\hline & \multicolumn{8}{|c|}{ CLA dietary level (\%) } & \multirow[b]{3}{*}{ ANOVA $P$ value } \\
\hline & \multicolumn{2}{|c|}{0} & \multicolumn{2}{|c|}{0.5} & \multicolumn{2}{|c|}{0.75} & \multicolumn{2}{|c|}{1} & \\
\hline & Mean & SD & Mean & SD & Mean & SD & Mean & SD & \\
\hline \multicolumn{10}{|l|}{ Fatty acids (\%) } \\
\hline $14: 0$ & $4 \cdot 13$ & 0.42 & 3.99 & 0.30 & $3 \cdot 75$ & 0.38 & 4.05 & 0.41 & $0 \cdot 183$ \\
\hline $16: 0$ & $17 \cdot 27$ & $1 \cdot 21$ & $17 \cdot 22$ & 0.74 & $16 \cdot 83$ & 0.74 & $17 \cdot 17$ & 0.66 & 0.695 \\
\hline $18: 0$ & $3 \cdot 95^{\mathrm{a}}$ & 0.18 & $4 \cdot 53^{b}$ & 0.23 & $4 \cdot 49^{\mathrm{b}}$ & 0.56 & $4 \cdot 50^{\mathrm{b}}$ & 0.38 & 0.005 \\
\hline Other saturated & 1.85 & 0.12 & $1 \cdot 82$ & 0.19 & 1.79 & 0.16 & 1.79 & 0.18 & 0.846 \\
\hline$\Sigma$ Saturated $^{*}$ & $27 \cdot 20$ & $1 \cdot 77$ & $27 \cdot 56$ & 0.96 & $26 \cdot 85$ & $1 \cdot 27$ & $27 \cdot 51$ & 0.84 & 0.618 \\
\hline $16: 1$ & $5 \cdot 11$ & 0.38 & $4 \cdot 74$ & 0.21 & 4.49 & 0.77 & 4.90 & 0.38 & 0.156 \\
\hline $18: 1$ & $18 \cdot 25$ & $1 \cdot 11$ & $17 \cdot 03$ & 1.57 & $17 \cdot 43$ & $1 \cdot 22$ & $17 \cdot 55$ & 0.58 & 0.193 \\
\hline $20: 1$ & $4 \cdot 14$ & 0.15 & $4 \cdot 13$ & 0.22 & 4.07 & 0.20 & 3.95 & 0.18 & 0.132 \\
\hline Other monounsaturated & 3.55 & 0.37 & 3.50 & 0.19 & 3.40 & 0.41 & 3.50 & $0 \cdot 16$ & 0.721 \\
\hline$\Sigma$ Monounsaturated $\dagger$ & 31.06 & 1.03 & $29 \cdot 40$ & 1.42 & $29 \cdot 39$ & 1.95 & 29.91 & 0.84 & 0.049 \\
\hline $18: 2 n-6$ & 4.56 & 0.28 & 4.62 & 0.34 & $4 \cdot 60$ & 0.52 & $4 \cdot 68$ & 0.34 & 0.918 \\
\hline $18: 2$ CLA & $0 \cdot 17^{\mathrm{a}}$ & 0.14 & $1 \cdot 24^{b}$ & 0.21 & $1 \cdot 60^{c}$ & 0.23 & $2 \cdot 10^{d}$ & 0.37 & 0.000 \\
\hline $18: 3 n-3$ & $1 \cdot 07$ & 0.04 & 1.04 & 0.08 & 0.97 & 0.10 & 1.04 & 0.11 & 0.105 \\
\hline $18: 4 n-3$ & 1.61 & $0 \cdot 12$ & 1.64 & 0.05 & 1.52 & $0 \cdot 10$ & 1.63 & $0 \cdot 12$ & 0.055 \\
\hline $20: 4 n-6$ & 0.76 & 0.05 & 0.77 & 0.06 & 0.77 & 0.05 & 0.74 & 0.04 & 0.512 \\
\hline $20: 4 n-3$ & $1 \cdot 27$ & $0 \cdot 11$ & $1 \cdot 31$ & 0.07 & $1 \cdot 23$ & 0.09 & $1 \cdot 22$ & 0.07 & 0.083 \\
\hline $20: 5 n-3$ & 5.96 & 0.57 & $6 \cdot 18$ & 0.25 & 5.90 & 0.17 & $5 \cdot 90$ & 0.19 & 0.164 \\
\hline $22: 5 n-6$ & $0.35^{a}$ & 0.08 & $0.22^{b}$ & 0.11 & $0.32^{\mathrm{ab}}$ & 0.07 & $0.28^{a b}$ & 0.09 & 0.024 \\
\hline $22: 5 n-3$ & $2 \cdot 06$ & $0 \cdot 12$ & $2 \cdot 15$ & 0.11 & 2.08 & 0.11 & 1.95 & 0.33 & 0.514 \\
\hline $22: 6 n-3$ & $19 \cdot 19$ & $1 \cdot 81$ & $19 \cdot 71$ & $1 \cdot 61$ & 19.94 & $2 \cdot 67$ & $18 \cdot 56$ & 2.07 & 0.514 \\
\hline Other polyunsaturated & $1 \cdot 82^{\mathrm{a}}$ & 0.37 & $1 \cdot 17^{\mathrm{b}}$ & 0.35 & $1.47^{\mathrm{ab}}$ & 0.30 & $1 \cdot 60^{\mathrm{ab}}$ & 0.39 & 0.005 \\
\hline$\Sigma$ Polyunsaturated $\ddagger$ & $38 \cdot 82$ & $2 \cdot 54$ & $40 \cdot 10$ & 1.50 & $40 \cdot 41$ & 2.49 & $39 \cdot 70$ & 1.92 & 0.443 \\
\hline$\Sigma n-3$ & $31 \cdot 72$ & $2 \cdot 54$ & 32.52 & 1.75 & $32 \cdot 11$ & 2.66 & $30 \cdot 82$ & 2.07 & 0.446 \\
\hline Total CLA (\%)§ & $0.44^{a}$ & $0 \cdot 15$ & $2 \cdot 10^{\mathrm{ab}}$ & 0.35 & $2 \cdot 74^{\mathrm{bc}}$ & 0.66 & $4 \cdot 16^{\mathrm{c}}$ & 0.54 & 0.000 \\
\hline $18: 2$ cis-9,trans-11(\%)\| & $0.05^{\mathrm{a}}$ & 0.02 & $0.83^{b}$ & 0.14 & $1 \cdot 13^{c}$ & 0.24 & $1 \cdot 74^{d}$ & $0 \cdot 15$ & 0.000 \\
\hline $18 \cdot 2$ trans-10 cis-12(\%)\| & $0.02^{\mathrm{a}}$ & $0 \cdot 01$ & $0.66^{b}$ & 0.10 & $0.92^{c}$ & 0.25 & $1 \cdot 39^{d}$ & $0 \cdot 12$ & 0.000 \\
\hline Total lipids (\%) & $4 \cdot 84$ & 0.61 & $5 \cdot 11$ & 0.71 & 4.92 & $1 \cdot 24$ & $4 \cdot 22$ & 0.50 & 0.293 \\
\hline
\end{tabular}

a,b,c,d Mean values with unlike superscript letters were significantly different $(P<0.05)$.

*Saturated: $12: 0,14: 0,14: 0$ isobr, 15:0,16:0,16:0 isobr, 17:0, 18:0,19:0, 20:0, 22:0 and $24: 0$.

† Monounsaturated: $16: 1 n-7,17: 1 n-8,18: 1 n-9,18: 1 n-7,20: 1 n-9,20: 1 n-7,22: 1 n-11$ and $22: 1 n-9$

† Polyunsaturated: $16: 2 n-4,16: 3 n-3,16: 4 n-3,18: 2 n-6,18: 2 C L A, 18: 3 n-6,18: 3 n-3,18: 4 n-3,20: 2 n-6,20: 4 n-6,20: 3 n-3,20: 4 n-3,22: 2 n-6,20: 5 n-3$, $22: 4 n-6,22: 5 n-6,22: 5 n-3$ and $22: 6 n-3$

$\S$ Sum of all CLA isomers detected by HPLC.

|| Isomers detected by HPLC. 
the biologically active trans-10, cis-12 and cis-9, trans-11 CLA isomers. The total CLA content of the muscle reflected the dietary inclusion levels, the highest level being attained when fish were fed 1\% CLA. The n-3 PUFA, in particular 20:5n-3 (EPA), $22: 5 n-3$ (docosapentaenoic acid) and $22: 6 n-3$ (DHA), were not affected by dietary CLA inclusion.

Contrary to what was observed in muscle, the liver fat content was significantly reduced by the inclusion of $0.75 \%$ or $1 \%$ CLA (Table 6). The ingestion of increasing amounts of CLA induced significant changes in the fatty acid profile of the liver that were reflected in all fractions. Both saturated and polyunsaturated fractions increased significantly with CLA incorporation, whereas there was a significant reduction in MUFA. The most evident changes in saturated fatty acids and MUFA were related to the increase in 18:0 and decrease in 18:1 fatty acids. With regard to PUFA, the levels of 18:2 CLA were significantly raised as a result of both biologically active isomers, although the incorporation of the cis-9,trans-11 isomer was always greater. Moreover, the liver deposition of 20:5n-3 (EPA) and of $22: 5 n-3$ (docosapentaenoic acid) showed the opposite trend: the level of the former increased significantly, whereas that of docosapentaenoic acid declined with dietary CLA incorporation. DHA deposition was similar in all treatments.

\section{Activities of lipogenic enzymes}

Data on the activities of the three lipogenic enzymes assayed are reported as both IU/mg protein and IU/100 g whole fish (Table 7). Glucose-6-phosphate dehydrogenase and fatty acid synthetase displayed the highest $(7 \cdot 8-8.9 \mathrm{IU} / 100 \mathrm{~g})$ and lowest (60-90 mIU/100 g) activity values, respectively, but dietary CLA level had no significant effect on either of these two lipogenic enzymes. Malic enzyme activity in fish fed $0.75 \%$ CLA was lower than that in fish fed the control diet ( $0 \%$ CLA), although this difference was less evident when the results were expressed per $100 \mathrm{~g}$ fish.

\section{Sensory analysis}

All panelists correctly identified the hidden control, and non-significant differences were detected between the panelists' results $(P<0 \cdot 01)$. Sensory data indicated significant

Table 6. Fatty acid profile (\% total fatty acids), total conjugated linoleic acid (CLA; \% total lipids) content, CLA isomers (\% total lipids) and total lipids (\% wet weight) in the liver of rainbow trout fed different dietary levels of CLA (0\%, $0.5 \%, 0.75 \%, 1 \%)$ for 12 weeks

(Mean values and standard deviations for six determinations)

\begin{tabular}{|c|c|c|c|c|c|c|c|c|c|}
\hline & \multicolumn{8}{|c|}{ CLA dietary level (\%) } & \multirow[b]{3}{*}{ ANOVA $P$ value } \\
\hline & \multicolumn{2}{|c|}{0} & \multicolumn{2}{|c|}{0.5} & \multicolumn{2}{|c|}{0.75} & \multicolumn{2}{|c|}{1} & \\
\hline & Mean & SD & Mean & SD & Mean & SD & Mean & SD & \\
\hline \multicolumn{10}{|l|}{ Fatty acids (\%) } \\
\hline $14: 0$ & 1.90 & $1 \cdot 33$ & 1.73 & 0.20 & 1.65 & 0.31 & 1.73 & 0.35 & 0.421 \\
\hline $16: 0$ & $13 \cdot 51$ & $1 \cdot 72$ & $14 \cdot 24$ & 0.70 & $15 \cdot 45$ & 1.66 & $14 \cdot 88$ & 0.55 & 0.174 \\
\hline $18: 0$ & $5 \cdot 64^{a}$ & 0.34 & $8 \cdot 26^{b}$ & 0.92 & $8 \cdot 01^{b}$ & 0.70 & $8 \cdot 44^{\mathrm{b}}$ & 1.07 & 0.000 \\
\hline Other saturated & $2 \cdot 10$ & $1 \cdot 10$ & 1.68 & 0.18 & 1.68 & 0.29 & $1 \cdot 77$ & 0.23 & 0.575 \\
\hline$\Sigma$ Saturated $^{*}$ & $23 \cdot 15^{a}$ & $1 \cdot 74$ & $25 \cdot 90^{\mathrm{b}}$ & 0.72 & $26 \cdot 79^{\mathrm{b}}$ & $1 \cdot 37$ & $26 \cdot 82^{b}$ & 1.00 & 0.000 \\
\hline $16: 1$ & 2.51 & $1 \cdot 20$ & $1 \cdot 13$ & 0.82 & $2 \cdot 88$ & 2.93 & 1.77 & 0.78 & 0.069 \\
\hline $18: 1$ & $17 \cdot 14^{\mathrm{a}}$ & $1 \cdot 82$ & $11 \cdot 80^{\mathrm{b}}$ & $2 \cdot 13$ & $11 \cdot 38^{\mathrm{b}}$ & $2 \cdot 68$ & $11 \cdot 20^{\mathrm{b}}$ & $2 \cdot 68$ & 0.001 \\
\hline $20: 1$ & 4.00 & 0.68 & $3 \cdot 17$ & 0.13 & $2 \cdot 79$ & 0.65 & 2.98 & 0.38 & $0 \cdot 102$ \\
\hline Other monounsaturated & 1.02 & $0 \cdot 10$ & 0.88 & 0.20 & 0.83 & 0.28 & 0.87 & 0.26 & 0.490 \\
\hline$\Sigma$ Monounsaturated $\dagger$ & $24 \cdot 62^{a}$ & $3 \cdot 12$ & $16 \cdot 98^{b}$ & $2 \cdot 16$ & $17 \cdot 87^{\mathrm{ab}}$ & $2 \cdot 69$ & $16 \cdot 81^{\mathrm{b}}$ & 3.86 & 0.008 \\
\hline $18: 2 n-6$ & $2 \cdot 38$ & 0.37 & 1.90 & 0.46 & $2 \cdot 10$ & 0.28 & $2 \cdot 36$ & 0.76 & 0.311 \\
\hline $18: 2$ CLA & $0 \cdot 11^{a}$ & $0 \cdot 14$ & $0.57^{b}$ & 0.12 & $0 \cdot 73^{b}$ & 0.24 & $1.07^{c}$ & 0.20 & 0.000 \\
\hline $18: 3 n-3$ & 0.38 & 0.22 & 0.46 & 0.09 & 0.44 & 0.08 & 0.50 & 0.13 & 0.487 \\
\hline $18: 4 n-3$ & 0.35 & $0 \cdot 10$ & 0.33 & 0.13 & 0.37 & 0.12 & 0.40 & 0.15 & 0.810 \\
\hline $20: 4 n-6$ & 2.39 & $0 \cdot 71$ & $3 \cdot 13$ & 0.56 & $2 \cdot 85$ & 0.90 & 3.37 & 0.51 & $0 \cdot 177$ \\
\hline $20: 4 n 3$ & 1.03 & 0.08 & 0.85 & 0.25 & 0.85 & 0.23 & 0.99 & 0.08 & 0.339 \\
\hline $20: 5 n-3$ & $5 \cdot 20^{a}$ & $1 \cdot 36$ & $6 \cdot 25^{\mathrm{ab}}$ & 1.52 & $7 \cdot 28^{\mathrm{b}}$ & 0.89 & $7 \cdot 60^{b}$ & 0.30 & 0.002 \\
\hline $22: 5 n-6$ & 0.59 & $0 \cdot 10$ & 0.69 & 0.04 & 0.62 & 0.12 & 0.67 & 0.06 & $0 \cdot 211$ \\
\hline $22: 5 n-3$ & $2 \cdot 85^{\mathrm{a}}$ & 0.35 & $2 \cdot 27^{\mathrm{ab}}$ & 0.15 & $2 \cdot 16^{b}$ & 0.10 & $2 \cdot 06^{b}$ & 0.19 & 0.000 \\
\hline $22: 6 n-3$ & $29 \cdot 98$ & 2.45 & $32 \cdot 15$ & $1 \cdot 20$ & $32 \cdot 91$ & 1.83 & 31.67 & $2 \cdot 32$ & 0.109 \\
\hline Other polyunsaturated & 1.58 & $0 \cdot 30$ & 1.59 & 0.53 & $1 \cdot 25$ & 0.21 & $1 \cdot 25$ & 0.26 & 0.167 \\
\hline$\Sigma$ Polyunsaturated $\ddagger$ & $47 \cdot 17^{a}$ & 3.53 & $50 \cdot 37^{\mathrm{ab}}$ & 1.84 & $51 \cdot 60^{\mathrm{b}}$ & 1.95 & $51.99^{b}$ & 1.62 & 0.008 \\
\hline$\Sigma n-3$ & $40 \cdot 16^{a}$ & $3 \cdot 26$ & $42 \cdot 61^{\mathrm{ab}}$ & 1.69 & $44 \cdot 26^{\mathrm{b}}$ & 2.08 & $43.45^{\mathrm{ab}}$ & 1.95 & 0.035 \\
\hline Total CLA (\%)§ & $0.29^{a}$ & 0.01 & $0.82^{a b}$ & 0.06 & $1 \cdot 29^{b}$ & 0.26 & $1.98^{\mathrm{b}}$ & 0.20 & 0.000 \\
\hline $18: 2$ cis-9,trans-11 (\%)\| & $0.05^{\mathrm{a}}$ & 0.00 & $0.35^{b}$ & 0.02 & $0.58^{c}$ & 0.10 & $0.85^{d}$ & 0.13 & 0.000 \\
\hline $18: 2$ trans-10, cis-12 (\%)\| & $0.02^{a}$ & 0.00 & $0.17^{b}$ & 0.03 & $0.30^{c}$ & $0 \cdot 10$ & $0.50^{d}$ & 0.06 & 0.000 \\
\hline Total lipids (\%) & $5 \cdot 80^{\mathrm{a}}$ & $1 \cdot 19$ & $4.69^{a b}$ & 0.51 & $4.09^{b}$ & 0.51 & $4 \cdot 09^{b}$ & 0.49 & 0.014 \\
\hline
\end{tabular}

a,b,c Mean values with unlike superscripts letters were significantly different $(P<0.05)$.

* Saturated: 12:0, 14:0,14:0 isobr, 15:0,16:0,16:0 isobr, 17:0, 18:0, 19:0, 20:0, 22:0 and 24:0.

† Monounsaturated: $16: 1 n-7,17: 1 n-8,18: 1 n-9,18: 1 n-7,20: 1 n-9,20: 1 n-7,22: 1 n-11$ and $22: 1 n-9$

ł Polyunsaturated: $16: 2 n-4,16: 3 n-3,16: 4 n-3,18: 2 n-6,18: 2 C L A, 18: 3 n-6,18: 3 n-3,18: 4 n-3,20: 2 n-6,20: 4 n-6,20: 3 n-3,20: 4 n-3,22: 2 n-6,20: 5 n-3,22: 4 n-6,22: 5 n-6$, $22: 5 n-3$ and $22: 6 n-3$.

$\S$ Sum of all CLA isomers detected by HPLC.

|| Isomers detected by HPLC. 
Table 7. Effects of different dietary levels $(0 \%, 0.5 \%, 0.75 \%$ and $1 \%)$ of conjugated linoleic acid (CLA) on the hepatic lipogenic enzyme activities of rainbow trout

(Mean values and standard deviations for nine determinations)

\begin{tabular}{|c|c|c|c|c|c|c|c|c|c|}
\hline & \multicolumn{8}{|c|}{ CLA dietary level (\%) } & \multirow[b]{3}{*}{ ANOVA $P$ value } \\
\hline & \multicolumn{2}{|c|}{0} & \multicolumn{2}{|c|}{0.5} & \multicolumn{2}{|c|}{0.75} & \multicolumn{2}{|c|}{1} & \\
\hline & Mean & SD & Mean & SD & Mean & SD & Mean & SD & \\
\hline \multicolumn{10}{|l|}{ Malic enzyme } \\
\hline $\mathrm{IU} / 100 \mathrm{~g}$ fish & 5.96 & 1.34 & $6 \cdot 10$ & 1.13 & 4.62 & 1.15 & $5 \cdot 64$ & 1.00 & 0.047 \\
\hline $\mathrm{mlU} / \mathrm{mg}$ protein & $62 \cdot 10^{\mathrm{a}}$ & $16 \cdot 08$ & $52 \cdot 69^{\mathrm{ab}}$ & 11.03 & $43 \cdot 66^{b}$ & 11.29 & $52 \cdot 23^{\mathrm{ab}}$ & $10 \cdot 47$ & 0.032 \\
\hline \multicolumn{10}{|c|}{ Glucose-6-phosphate dehydrogenase } \\
\hline $\mathrm{IU} / 100 \mathrm{~g}$ fish & 8.92 & 1.40 & 8.78 & 2.09 & 8.06 & $1 \cdot 14$ & 7.83 & $2 \cdot 30$ & 0.507 \\
\hline mlU/mg protein & $92 \cdot 34$ & 14.65 & 73.93 & $19 \cdot 47$ & $78 \cdot 15$ & $18 \cdot 01$ & $72 \cdot 47$ & 21.07 & 0.110 \\
\hline \multicolumn{10}{|c|}{ Fatty acid synthetase } \\
\hline $\mathrm{mlU} / 100 \mathrm{~g}$ fish & 63.83 & 31.55 & $66 \cdot 47$ & 57.03 & $87 \cdot 70$ & $86 \cdot 42$ & 66.90 & 37.53 & 0.799 \\
\hline $\mathrm{mlU} / \mathrm{mg}$ protein & 0.53 & 0.25 & 0.50 & 0.47 & 0.77 & 0.68 & 0.48 & 0.32 & 0.514 \\
\hline
\end{tabular}

${ }^{\mathrm{a}, \mathrm{b}}$ Mean values with unlike superscript letters were significantly different $(P<0.05)$.

differences in the organoleptic characteristics between trout fed the control diet and trout fed the different CLA levels $(0.5 \%, 0.75 \%, 1 \%$ CLA). These differences were classified as slight-to-moderate for $0.5 \%$ and $0.75 \%$ CLA, and between slight and slight-to-moderate for $1 \%$ CLA, suggesting that CLA levels above $0.75 \%$ were less perceptible in sensory terms than were lower values. Descriptors from the panelists included attributes of flavour and texture in the mouth, although panelists were divided concerning their preferences: approximately half of the panelists had the overall impression that the samples with CLA were better than the control, whereas the other half expressed the opposite view.

\section{Discussion}

The growth rates and nutrient utilisation of rainbow trout were good, and the incorporation of increasing dietary levels of CLA $(0-1 \%)$ led to similar final weights of the fish at the end of the 12-week trial. Moreover, the independency of growth performance upon dietary CLA level confirm earlier observations in juvenile rainbow trout growing from 5 to $70 \mathrm{~g}$ and fed low-fat diets with the same CLA level (Figueiredo-Silva et al. 2005), and are in agreement with results from other studies in various fish species fed 0.5$5 \%$ CLA (Twibell et al. 2001; Twibell \& Wilson, 2003; Berge et al. 2004; Kennedy et al. 2005). However, common carp fed $1 \%$ CLA increased their weight gain (Choi et al. 1999), whereas hybrid striped bass reduced their feed intake and improved their feed efficiency (Twibell et al. 2000). Nevertheless, higher CLA inclusion levels reduced weight gain and feed efficiency in Nile tilapia, rockfish and common carp (Choi et al. 1999). It can be concluded that the effect of CLA on growth performance and feed efficiency is clearly dependent on the species considered.

In the present study, dietary CLA up to $1 \%$ had no effect on the whole-body composition of rainbow trout, which is in agreement with previous findings in smaller-sized trout (Figueiredo-Silva et al. 2005), hybrid striped bass (Twibell et al. 2000), channel catfish (Twibell \& Wilson, 2003) and Atlantic salmon (Kennedy et al. 2005). Several studies have, however, reported a decrease in lipid deposition in certain fish species (Choi et al. 1999; Twibell et al. 2000, 2001;
Twibell \& Wilson, 2003). The reduction in lipid deposition is particularly desirable when high-fat diets are used. In the present study, however, CLA administration did not affect the body composition of the fish.

With respect to the influence of CLA on tissue composition, a decrease in liver lipid content was obtained when high levels of CLA $(>0.5 \%)$ were fed. This is in accordance with earlier results from striped bass (Twibell et al. 2000) and yellow perch (Twibell et al. 2001). In contrast, dietary CLA had no significant effect on the liver lipid content of catfish (Twibell \& Wilson, 2003), Atlantic salmon (Kennedy et al. 2005) or rainbow trout juveniles fed low-fat diets (Bandarra et al. 2006), whereas increased muscle lipid concentrations were observed in Atlantic salmon (Kennedy et al. 2005). In the present work, the hepatosomatic index was not affected by different CLA treatments, despite the reduction in liver lipid content by dietary CLA supplementation.

The reduction in liver lipid content was accompanied by a slight reduction in malic enzyme specific activity, whereas glucose-6-phosphate dehydrogenase and fatty acid synthetase were not significantly affected by the dietary CLA level. The positive correlation between malic enzyme specific activity and liver lipid content suggests an inhibition of malic enzyme activity and consequent liver lipid content by increasing dietary CLA levels. An inhibition of de novo lipogenesis by CLA isomers has been demonstrated in the mammary glands of sow (Bee, 2000) and mice (Lin et al. 2004). Moreover, other studies have demonstrated that CLA upregulates not only the mRNA expression, but also the activity of various enzymes involved in lipogenesis and fatty acid oxidation in mouse liver (Takahashi et al. 2003; Ide, 2005). In rats, the ingestion of a CLA mixture increased malic enzyme activity in the liver, whereas the activities of both glucose-6-phosphate dehydrogenase and fatty acid synthetase were unaffected (Faulconnier et al. 2004). Figueiredo-Silva et al. (2005) did not observe any significant changes in the activities of the lipogenic enzymes in rainbow trout juveniles fed low-fat diets (16\%) and increasing CLA levels, suggesting that the effect of CLA on hepatic lipogenic enzymes was dependent on the species considered and might be related to the various nutritional and physiological conditions involved in the regulation of hepatic fatty acid oxidation and synthesis. 
Several studies have shown that the dietary CLA affects the fatty acid profile of fish independently of any effect on body fat level (Twibell et al. 2000; Berge et al. 2004; Bandarra et al. 2006). In the present work, the total percentage of the main fatty acids groups in muscle were not as strongly affected by the dietary inclusion of CLA as they were in rainbow trout juveniles fed low-fat diets (Bandarra et al. 2006). This suggests that the developmental stage of the fish and the dietary lipid content might affect the pattern of lipid metabolism. The saturated lipid fraction in muscle did not vary between dietary treatments despite the increasing concentration of stearic acid (18:0). In liver, however, the saturated fraction of the control group was significantly lower than that found in fish fed CLA, stearic acid concentration being mainly responsible for these differences. This was a clear effect of dietary CLA as the control diet contained higher amounts of saturated fatty acids. Moreover, the level of MUFA decreased significantly in both muscle and liver. The significant increase in 18:0 and the concomitant decrease in 18:1n-9 suggests an inhibition of $\Delta-9$ desaturase activity by CLA. This was more evident in liver than muscle. Similar results have been reported in rainbow trout juveniles (Bandarra et al. 2006), hybrid striped bass (Twibell et al. 2000), yellow perch (Twibell et al. 2001) and Atlantic salmon (Berge et al. 2004; Kennedy et al. 2005). The dietary incorporation of CLA led to a significant increase in the polyunsaturated fraction in the liver. In muscle, besides CLA deposition, a reduction in $22: 5 n-6$ was observed, whereas the $n-3$ fatty acid concentrations remained unchanged. Different results were previously reported in rainbow trout juveniles (Bandarra et al. 2006) and striped bass muscle (Twibell et al. 2000), for which CLA incorporation resulted in decreased levels of DHA $(22: 6 n-3)$. In larger rainbow trout $(>250 \mathrm{~g})$, this negative effect was not observed in muscle and liver, where a prominent biosynthesis and deposition of DHA was reported.

CLA was successfully incorporated into tissue lipids, levels in flesh being 2 -fold higher $(2 \cdot 1-4.2 \%)$ than those in liver $(0 \cdot 8-1.9 \%)$. Moreover, muscle CLA incorporation was not related to a decrease in DHA, as previously reported in juvenile rainbow trout fed low-fat diets (Bandarra et al. 2006), as well as other species (Twibell et al. 2000; Kennedy et al. 2005). In muscle and liver lipids, cis-9,trans-11 and trans10 ,cis-12 isomers were retained in proportions similar to those found in the diets. Results reported by Burdge et al. (2004) show that there was no differential incorporation of cis-9,trans-11 and trans-10,cis-12 into the plasma phospholipids of healthy men. Nevertheless, the extent of incorporation of total CLA isomers seems to be tissue dependent, showing a higher deposition in muscle lipid than liver, as previously reported for rainbow trout juveniles (Bandarra et al. 2006), Atlantic salmon (Kennedy et al. 2005) and mammalian species (Ostrowska et al. 2003; Lauridsen et al. 2005).

It is well known that different dietary fat sources will affect the fatty acid composition of fish, and that this can be reflected in their sensory qualities (Boggio et al. 1985; Turchini et al. 2003; Izquierdo et al. 2005). In the present study, the sensory characteristics of trout fillet were slightly affected by the dietary supplementation with CLA. Schabbel et al. (2004) did not find any difference in trout previously fed with diets containing $0 \%, 1 \%$ and $3 \%$ CLA, although the flavour of deep-frozen fillets with $3 \%$ CLA and $600 \mathrm{mg}$ vitamin E supplementation was considered to be positively distinct.
The results obtained in the present experiment clearly show that CLA can be incorporated in a proportion of up to $1 \%$ in rainbow trout diets without altering fish performance, feed efficiency and whole-body composition. The effects of CLA in liver metabolism were more pronounced than reported in previous studies (Figueiredo-Silva et al. 2005; Bandarra et al. 2006), suggesting that the dietary oil content and developmental stage of the fish are important factors in determining the effects of CLA. The present results clearly suggest that CLA can be incorporated at a level of up to $1 \%$ in rainbow trout diets, contributing to the production of a functional food. It is now important to determine the minimal administration period of dietary CLA to obtain the desirable deposition levels of CLA in the muscle of commercially sized rainbow trout.

\section{Acknowledgements}

Special thanks go to Sorgal, S.A., Ovar, Portugal, for supplying the extruded diet before coating, and to Bioriginal Food and Science Corp., Saskatoon SK, Canada, for offering the CLA mixture. We also thank António Júlio Pinto for his technical assistance during the growth trial and samplings, and Engs. Maria João Monteiro and Susana Teixeira, from Escola Superior de Biotecnologia, Universidade Católica Portuguesa, for their work and facilities for sensory testing. This study was supported by project POCTI/CVT/39237/2001 (FCT, Portugal, with the support of the European fund FEDER).

\section{References}

Association of Official Analytical Chemists (2000) Official Methods of Analysis of AOAC International: Method 963.22. Washington, DC: AOAC.

Bandarra M, Nunes ML, Andrade AM, Prates JAM, Pereira S, Monteiro M, Rema P \& Valente LMP (2006) Effect of dietary conjugated linoleic acid on muscle, liver and visceral lipid deposition in rainbow trout juveniles (Oncorhynchus mykiss). Aquaculture 254, 496-505.

Bautista JM, Garrido-Pertierra A \& Soler G (1988) Glucose-6-phosphate dehydrogenase from Dicentrarchus labrax liver: kinetic mechanism and kinetics of NADPH inhibition. Biochim Biophys Acta 967, 354-363.

Bee G (2000) Dietary conjugated linoleic acids alter adipose tissue and milk lipids of pregnant and lactating sows. J Nutr 130, 2292-2298.

Berge GM, Ruyter B \& Asgard T (2004) Conjugated linoleic acid in diets for juvenile Atlantic salmon (Salmo salar); effects on fish performance, proximate composition, fatty acid and mineral content. Aquaculture 237, 365-380.

Bligh E \& Dyer W (1959) A rapid method of total lipid extraction and purification. J Biochem Physiol 37, 911-917.

Boggio SM, Hardy RW, Babbitt JK \& Brannon EL (1985) The influence of dietary lipid source and alpha-tocopheryl acetate level on product quality of rainbow trout (Salmo gairdneri). Aquaculture 51, 13-24.

Bradford MM (1976) A rapid and sensitive method for the quantisation of microgram quantities of protein utilizing the principle of protein-dye binding. Ann Biochem 72, 248-254.

Burdge GC, Lupoli B, Russell JJ, et al. (2004) Incorporation of cis-9, trans-11 or trans-10,cis-12 conjugated linoleic acid into plasma and cellular lipids in healthy men. J Lipid Res 45, 736-741.

Chakrabarty K \& Leveille GA (1969) Acetyl-CoA carboxylase and fatty acid synthetase activities in the liver and adipose tissue of meal-fed rats. Proc Soc Exp Biol Med 131, 1051-1054. 
Chang HC, Seidman I, Teebor G \& Lane DM (1967) Liver acetylCoA carboxylase and fatty acid synthetase relative activities in the normal state and hereditary obesity. Biochem Biophys Res Commun 28, 682-686.

Choi BD, Kang SJ, Ha YL \& Ackman RG (1999) Accumulation of conjugated linoleic acid (CLA) in tissues of fish fed diets containing various levels of CLA. In Quality Attributes of Muscle Foods, pp. 61-71 [YL Xiong, CT Ho and F Shahidi, editors]. New York: Kluwer Academic/Plenum Publishers.

Corraze G (2001) Lipid nutrition. In Nutrition and Feeding of Fish and Crustaceans, pp. 111-130 [J Guillaume, S Kaushik, P Bergot and R Métailler, editors]. London: Springer Praxis.

Cowey CB (1993) Some effects of nutrition on the flesh quality of cultured fish. In Fish Nutrition in Practice, pp. 227-236 [SJ Kaushik and P Luquet, editors]. Paris: INRA Editions.

Faulconnier Y, Arnalb MA, Mirand PP, Chardignyc JM \& Chilliarda Y (2004) Isomers of conjugated linoleic acid decrease plasma lipids and stimulate adipose tissue lipogenesis without changing adipose weight in post-prandial adult sedentary or trained Wistar rat. J Nutr Biochem 15, 741-748.

Figueiredo-Silva AC, Rema P, Bandarra NM, Nunes M \& Valente LMP (2005) Effects of dietary conjugated linoleic acid in growth, nutrient utilization, body composition and hepatic lipogenesis in rainbow trout juveniles (Oncorhynchus mykiss). Aquaculture 248, 163-172.

Gaullier JM, Halse J, Hoye K, Kristiansen K, Fagertun H, Vik H \& Gudmundsen O (2005) Supplementation with conjugated linoleic acid for 24 months is well tolerated by and reduces body fat mass in healthy, overweight humans. J Nutr 135, 778-784.

Ha YL, Storkson J \& Pariza MW (1990) Inhibition of benzo(a)pyrene-induced mouse forestomach neoplasia by conjugated dienoic derivatives of linoleic acid. Cancer Res 50, 1097-1101.

Hillestad M \& Johnsen F (1994) High-energy/low-protein diets for Atlantic salmon: effects on growth, nutrient retention and slaughter quality. Aquaculture 124, 109-116.

Ide $\mathrm{T}$ (2005) Interaction of fish oil and conjugated linoleic acid in affecting hepatic activity of lipogenic enzymes and gene expression in liver and adipose tissue. Diabetes 54, 412-423.

Ip C, Banni S, Angioni E, Carta G, Mcginley J, Thompson HJ, Barbano D \& Bauman D (1999) Conjugated linoleic acid-enriched butter fat alters mammary gland morphogenesis and reduces cancer risk in rats. $J$ Nutr 129, 2135-2142.

Izquierdo MS, Montero D, Robaina L, Caballero MJ, Rosenlund G \& Gines R (2005) Alterations in fillet fatty acid profile and flesh quality in gilthead seabream (Sparus aurata) fed vegetable oils for a long term period. Recovery of fatty acid profiles by fish oil feeding. Aquaculture 250, 431-444.

Kennedy SR, Campbell PJ, Porter A \& Tocher DR (2005) Influence of dietary conjugated linoleic acid (CLA) on lipid and fatty acid composition in liver and flesh of Atlantic salmon (Salmon salar). Comp Biochem Physiol 141, 168-178.

Kramer JK, Blackadar CB \& Zhou J (2002) Evaluation of two GC columns (60 m Supelcowax 10 and $100 \mathrm{~m}$ CP Sil 88) for analysis of milkfat with emphasis on CLA, 18:1, 18:2 and 18:3 isomers, and short and long-chain fatty acids. Lipids 37, 823-835.

Lauridsen C, Mu H \& Henckel P (2005) Influence of dietary conjugated linoleic acid (CLA) and age at slaughtering on performance, slaughter-and meat quality, lipoproteins, and tissue deposition of CLA in barrows. Meat Sci 69, 393-399.

Lee KN, Kritchevsky D \& Pariza MW (1994) Conjugated linoleic acid and atherosclerosis in rabbits. Atherosclerosis 108, 19-25.

Li Y \& Watkins BA (1998) Conjugated linoleic acids alter bone fatty acid composition and reduce ex vivo prostaglandin E2 biosynthesis in rats fed $n-6$ or $n-3$ fatty acids. Lipids 33, 417-425.

Lin X, Loor JJ \& Herbein JH (2004) Trans10,cis12-18:2 is a more potent inhibitor of de novo fatty acid synthesis and desaturation than cis9,trans $11-18: 2$ in the mammary gland of lactating mice. $J$ Nutr 134, 1362-1368.

Ochoa S (1955) Malic enzyme. In Methods in Enzymology, vol. 1, pp. 739-753 [SP Colowick and NO Kaplan, editors]. New York: Academic Press.

Ostrowska E, Cross RF, Muralitharan M, Bauman DE \& Dunshea FR (2003) Dietary conjugated linoleic acid differentially alters fatty acid composition and increases conjugated linoleic acid content in porcine adipose tissue. Brit J Nutr 90, 925-928.

Ostrowska E, Muralitharan M, Cross RF, Bauman DE \& Dunshea FR (1999) Dietary conjugated linoleic acids increase lean tissue and decrease fat deposition in growing pigs. J Nutr 129, 2037-2042.

Park Y, Albright KJ, Cai ZY \& Pariza MW (2001) Comparison of methylation procedures for conjugated linoleic acid and artefact formation by commercial (trimethylsilyl) diazomethane. J Agric Food Chem 49, 1158-1164.

Park Y, Albright KJ, Liu W, Storkson JM, Cook ME \& Pariza MW (1997) Effect of conjugated linoleic acid on body composition in mice. Lipids 32, 853-858.

Risérus U, Arner P, Brismar K \& Vessby B (2002) Treatment with dietary trans 10 cis 12 conjugated linoleic acid causes isomerspecific insulin resistance in obese men with the metabolic syndrome. Diabetes Care 25, 1516-1521.

Risérus U, Smedman A, Basu S \& Vessby B (2003) CLA and body weight regulation in humans. Lipids 38, 133-137.

Schabbel W, Maаß D, Steinhart H, Reiter R \& Schwarz FJ (2004) Performance, carcass quality and fatty acid composition of trout (Salmo gairdnerii) as affected by dietary conjugated linoleic acid and vitamin E supplementation. Proc Soc Nutr Physiol 13, 49.

Sisk MB, Hausman DB, Martin RJ \& Azain MJ (2001) Dietary conjugated linoleic acid reduces adiposity in lean but not obese zucker rats. J Nutr 131, 1668-1674.

Szymczyk B, Pisulewski P, Szczurek W \& Hanczakowski P (2001) Effects of conjugated linoleic acid on growth, feed conversion efficiency, and subsequent carcass quality in broiler chickens. $\mathrm{Br} \mathrm{J}$ Nutr 85, 465-473.

Takahashi Y, Kushiro M, Shinohara K \& Ide T (2003) Activity and mRNA levels of enzyme involved in hepatic fatty acid synthesis and oxidation in mice fed conjugated linoleic acid. Biochim Biophys Commun 1631, 265-273.

Turchini GM, Mentasti T, Frøyland L, Orban E, Caprino F, Moretti VM \& Valfré F (2003) Effects of alternative dietary lipid sources on performance, tissue chemical composition, mitochondrial fatty acid oxidation capabilities and sensory characteristics in brown trout (Salmo trutta L.). Aquaculture 225, 251-267.

Twibell RG \& Wilson RP (2003) Effects of dietary conjugated linoleic acids and total dietary lipid concentrations on growth responses of juvenile channel catfish, Ictalurus puncatus. Aquaculture 221, $621-628$.

Twibell RG, Watkins BA, Rogers L \& Brown PB (2000) Effects of dietary conjugated linoleic acids on hepatic and muscle lipids in hybrid striped bass. Lipids 35, 155-161.

Twibell RG, Watkins BA \& Brown PB (2001) Dietary conjugated linoleic acids and lipid source alter fatty acid composition of juvenile yellow perch, Perca flavescens. J Nutr 131, 2322-2328.

Vergara JM, López-Calero G, Robaina L, Caballero MJ, Montero D, Izquierdo MS \& Aksnes A (1999) Growth, feed utilization and body lipid content of gilthead seabream (Sparus aurata) fed increasing lipid levels and fish meals of different quality. Aquaculture 179, 35-44.

West DB, DeLany JP, Camet PM, Blohm F, Truett AA \& Scimeca J (1998) Effects of conjugated linoleic acid on body fat and energy metabolism in the mouse. Am J Physiol 275, 667-672.

Zar JH (1996) Biostatistical Analysis. London: Prentice-Hall International. 